University of Nebraska - Lincoln

DigitalCommons@University of Nebraska - Lincoln

1973

\title{
Seismicity Preceding Moderate Earthquakes in California
}

Robert L. Wesson

U.S. Geological Survey

William L. Ellsworth

U.S. Geological Survey

Follow this and additional works at: https://digitalcommons.unl.edu/usgsstaffpub

Part of the Earth Sciences Commons

Wesson, Robert L. and Ellsworth, William L., "Seismicity Preceding Moderate Earthquakes in California" (1973). USGS Staff -- Published Research. 382.

https://digitalcommons.unl.edu/usgsstaffpub/382

This Article is brought to you for free and open access by the US Geological Survey at DigitalCommons@University of Nebraska - Lincoln. It has been accepted for inclusion in USGS Staff -- Published Research by an authorized administrator of DigitalCommons@University of Nebraska - Lincoln. 


\title{
Seismicity Preceding Moderate Earthquakes in California
}

\author{
Robert L. Wesson and William L. Ellsworth \\ National Center for Earthquake Research, U.S. Geological Survey \\ Menlo Park, California 94025
}

\begin{abstract}
Regional seismicity data have been examined to determine the nature of seismicity in the years preceding these moderate earthquakes in California: 1952 Kern County $(M=7.7)$, 1963 Watsonville $(M=5.4), 1964$ and 1967 Corralitos $(M=5.0,5.3), 1966$ Parkfield-Cholame $(M=5.1,5.5), 1968$ Borrego Mountain $(M=6.4), 1969$ Santa Rosa $(M=5.6,5.7)$, and 1971 San Fernando $(M=6.4)$. In each instance the moderate earthquakes occurred in areas characterized by a relatively high level of small earthquake activity. In most cases the preceding activity in the area immediately surrounding the epicenter was high relative to other segments of the same fault zone or other nearby fault zones that, on the basis of geologic criteria, would be considered equally likely locations for moderate earthquakes. Detailed observations for a moderate earthquake that occurred in 1972 near Bear Valley $(M=5.0)$, where seismograph station coverage is adequate to obtain reliable focal depths for small earthquakes, indicate that concentrations of small earthquakes were present in the immediate hypocentral region in the months before the earthquake. The regional observations have potential applications for the analysis of seismic risk in that fault zones or segments of fault zones characterized by a relatively large number of small earthquakes seem more likely to sustain moderate earthquakes than do adjacent fault zones or fault segments with equivalent geologic evidence for recency of movement. The detailed observations provide a potential tool for mapping stress concentrations or areas of anomalously low strength along the parts of fault zones capable of seismic slip.
\end{abstract}

The relation between small earthquake activity and the potential for moderate or larger earthquakes promises to provide powerful tools for the prediction of earthquakes. (For purposes of this discussion, 'small earthquakes' means earthquakes with local magnitudes less than magnitude 5. In this term we include 'microearthquakes,' which are generally taken to be earthquakes with local magnitudes less than 3.) Extensive evidence has been accumulated in the western United States and elsewhere that damaging shallow earthquakes occur along faults that can be (or could have been) demonstrated by geologic means to have sustained displacement in Quaternary time [e.g., Wentworth and Yerkes, 1971; Brown et al., 1967; Allen et al., 1968; Clark et al., 1972; Dibblee, 1955]. Before the development of dense local seismograph networks in the 1960's the accuracy of locating small earthquakes was such as to suggest that they occurred rather generally throughout an active region. With the development of dense seismograph networks and with careful attention to crustal velocity structure

Copyright $(C) 1973$ by the American Geophysical Union. it has been demonstrated that most small earthquakes and aftershocks in California are closely associated with geologically mappable faults [Lee, 1971; Eaton et al., 1970a, b; Hamilton, 1972; Wesson and Wilson, 1972]. In fact, it has become possible to 'map' many faults by the distribution of small earthquakes along them. In contrast, several sections (as long as $300 \mathrm{~km}$ ) of major fault zones that have sustained large displacements in historic time display a very low level of seismic activity at present [Lee, 1971; Brune and Allen, 1967; Page, 1972; Allen et al., 1965; Ryall et al., $1972 ;$ Byerly, 1937]. If studies of small earthquakes are to be useful in earthquake prediction, we must discover how the presence or absence of small earthquake activity relates to the potential for a moderate or large earthquake.

The answer to this question has in the past been shrouded by the difficulties of accurately locating small earthquakes and by uncertainty about the time scale on which preceding activity is important. Except for some well-defined foreshocks that occur within hours prior to a 
moderate or large earthquake, there is little or no evidence to suggest a buildup of small earthquakes in the days and weeks prior to the main shock [Richter, 1955a; Allen, 1971; McEvilly et al., 1967]. Richter has observed, however, that 'In 28 years of seismograph recording from 1929 through 1956 there was only one earthquake in southern California of magnitude 5, or over, which was not preceded by others from the same or an adjacent epicenter, although weeks or months might intervene between the last previous shock and the large one [Richter, 1958, p. 67].'

We have examined the seismicity data for some regions in which moderate earthquakes have occurred in California, for which adequate instrumental capability existed prior to the main shock, in order to determine the nature and distribution of the small earthquakes, if any, that occurred in the months and years preceding the main shock. Similar work has been done in Japan by Mogi [1968b, 1969] and in the Soviet Union by Keylis-Borok and Malinovskaya [1964] and Fedotov [1968].

\section{Method}

To study the seismicity of regions of California in which moderate earthquakes have occurred and for which an adequate instrumental capability existed prior to the earthquakes, we examined the published bulletins (and some as yet unpublished data) from the Seismological Laboratory, California Institute of Technology (Caltech), and from the Seismographic Stations, University of California, Berkeley (UCB), for the period since 1962. In addition we examined the Caltech data for the twenty years prior to the 1952 Kern County earthquake. Both seismograph networks operated by these two institutions are regional in nature, and both grew significantly during the 1960's. Both groups attempt to make their lists of earthquakes substantially complete above magnitude 3 , with many smaller earthquakes located as well. Under favorable circumstances the accuracy of epicenter location is probably within a few kilometers; under unfavorable circumstances the error is doubtless somewhat larger.

To make a truly convincing case that small and microearthquake activity is premonitory to a moderate or large earthquake, it would be desirable to establish a mechanistic relation- ship-for example, between the focal mechanisms and source parameters of the preceding small earthquakes and those of the main shock. Unfortunately, the data available offer only a crude suggestion of a spatial relationship; description of a causal relationship must await further studies.

To compare the pattern of seismicity prior to the main shock with the rupture surface or surfaces, we have characterized the main shock by its zone of aftershock activity, as has been done by Fedotov [1965], Mogi [1968a], and Sykes [1971]. This characterization has two qualities to recommend it. First, the zone of aftershocks seems to be a good approximation of the area of slip during the main event. Second, if the earthquakes used to define the aftershock zone have been located in the same way as those preceding the main shock, the definition of the aftershock zone contains an estimate of the uncertainty of the locations. For this reason we have generally chosen aftershock zones as defined by the earthquake locations from regional networks, rather than the more precise definition sometimes available from studies in which many additional stations are deployed.

The events selected for study are listed in Table 1. The distance to the closest station (or stations) is included to give some indication of the detection and location capability prior to the main shock. The locations of these events relative to the major faults of California are indicated in Figure 1.

In each of the moderate earthquakes studied we have selected a period for which we believed the locations were most reliable, or were at least consistent. We have plotted the epicenters of earthquakes within a region with dimensions a few to several times that of the aftershock zone.

\section{Observations}

1952 Kern County earthquake. The Kern County earthquake ( $M=7.7$ ) of July 21,1952 , is the largest earthquake recorded in California since a sufficient number of stations existed to detect and locate preceding activity. In this earthquake, thrusting in a northwesterly direction accompanied by left lateral slip occurred along a $50-\mathrm{km}$ section of the White Wolf fault at the southern end of the San Joaquin Valley [Dibblee, 1955; Buwalda and St. Armand, 


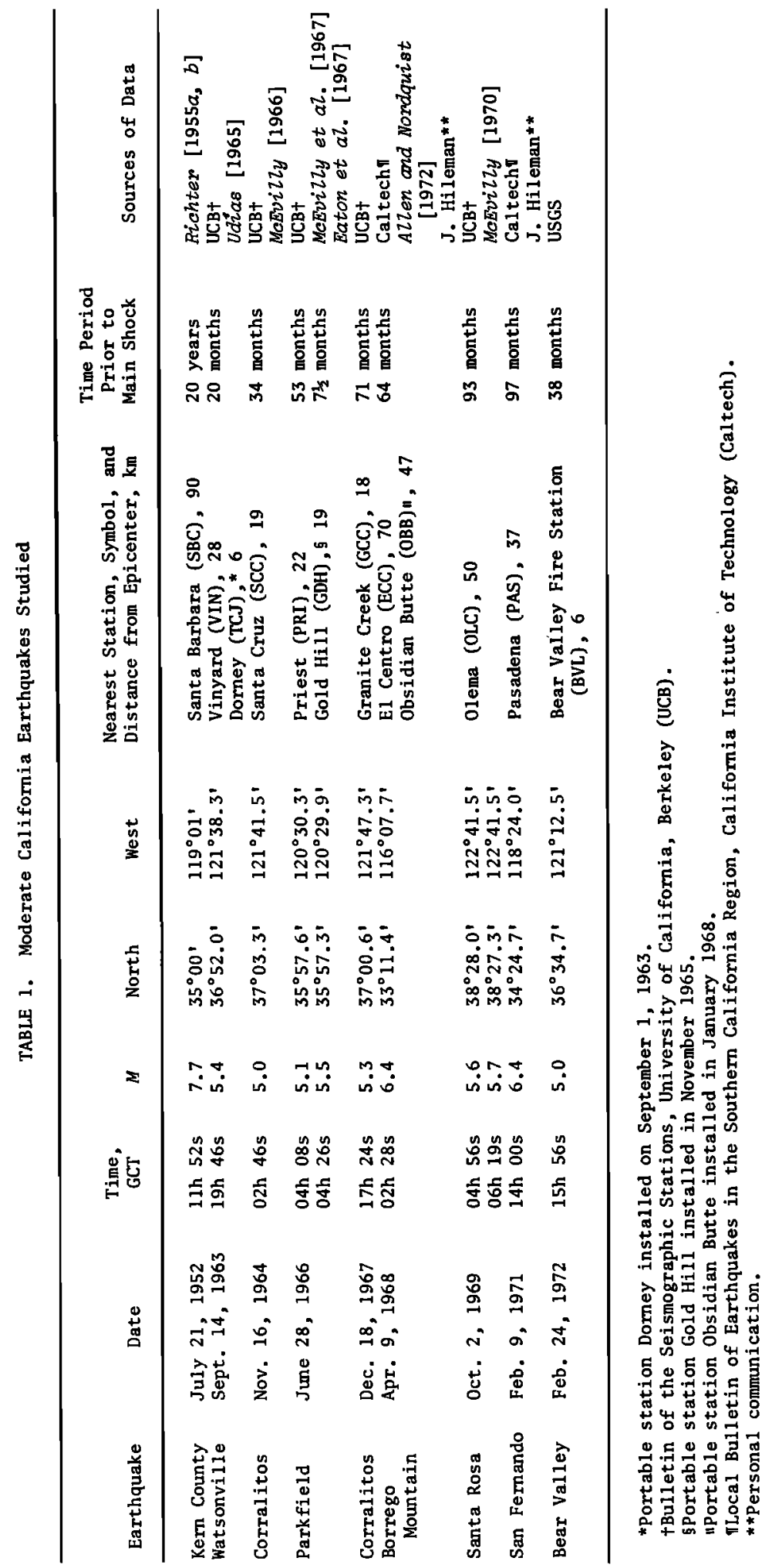




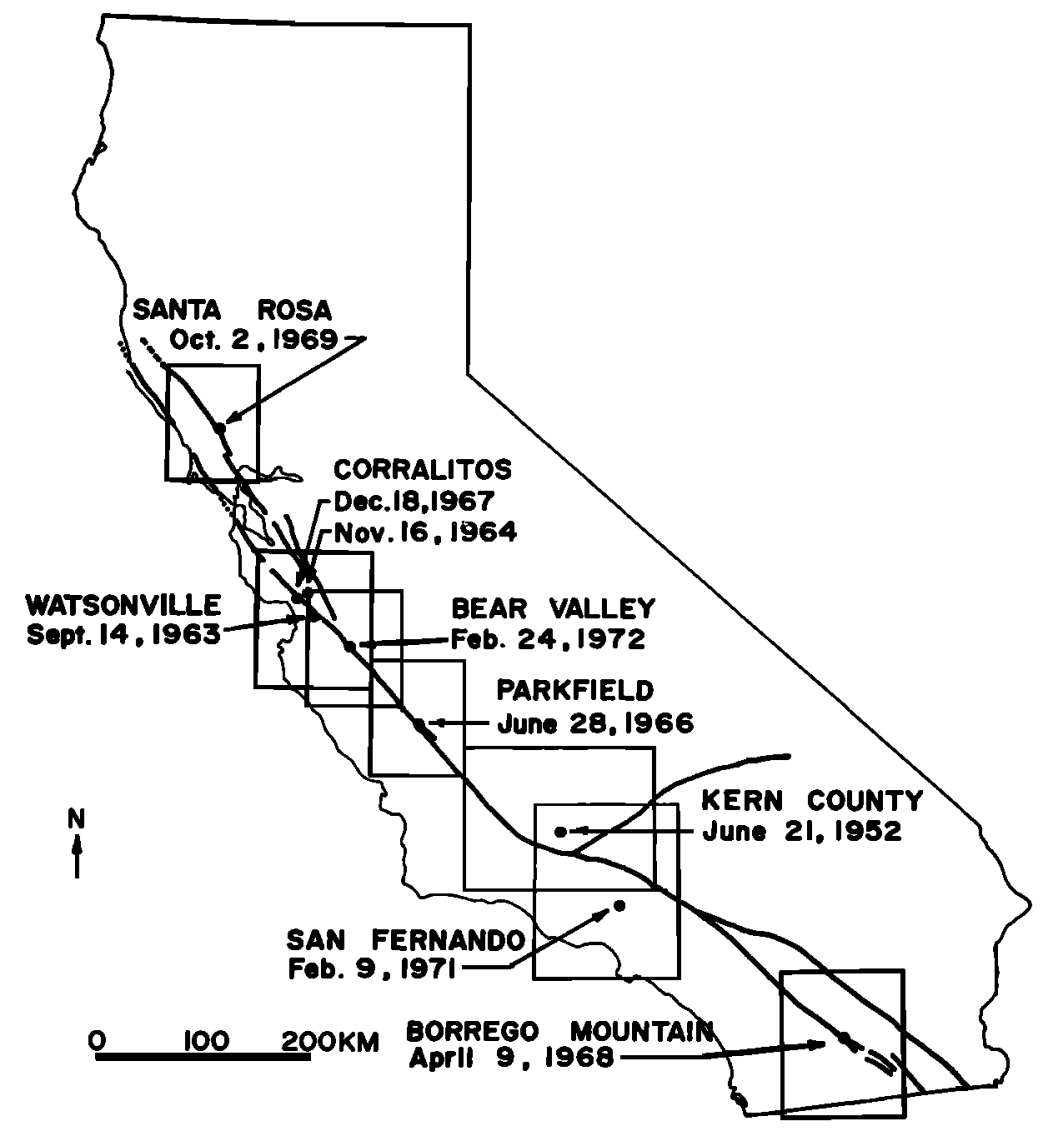

Fig. 1. Map of California showing the outlines of the seven regions surrounding the earthquakes. Also shown are the major faults of the San Andreas fault system.

1955]. Geologic evidence points to more than $3 \mathrm{~km}$ of vertical offset along this fault since the beginning of Pleistocene time. However, the fault had not been recognized as a contemporary earthquake hazard prior to the 1952 earthquakes [Oakeshott, 1955]. Richter [1955b], in discussing activity preceding the earthquake, concluded, 'There was little prelude to the major earthquake of July 21, 1952.' Although the data available suggest that this is true on time scales of less than a few years, it is certainly not true on a time scale of many years. Locations of earthquakes in the 20 years preceding the main shock [Richter, 1955a] show that the activity within about $15 \mathrm{~km}$ of the epicenter was substantially higher than activity in most of the surrounding region (see Figure 2). In particular, the activity in the vicinity of the epicenter was very much greater than the activity along either the San Andreas or Gar- lock faults, both of which were very active in Quaternary time. The region of the San Andreas fault south and west of the White Wolf fault was the site of a great earthquake in 1857 , with ground breakage that extended for $250 \mathrm{~km}$ or more [Richter, 1958]. Of particular interest in the 1952 earthquake is that, although the region of the aftershock zone containing the epicenter of the main shock, and presumably the initiation of rupture, was relatively active before the main shock, the opposite end of the aftershock zone was relatively quiet. The aftershocks were concentrated at opposite ends of the zone.

1969 Watsonville and 1964 and 1967 Corralitos earthquakes. Earthquakes in the Watsonville-Corralitos area are of particular interest because they are located at the northern terminus of the $200-\mathrm{km}$-long zone of relatively high seismicity along the San Andreas fault in cen- 


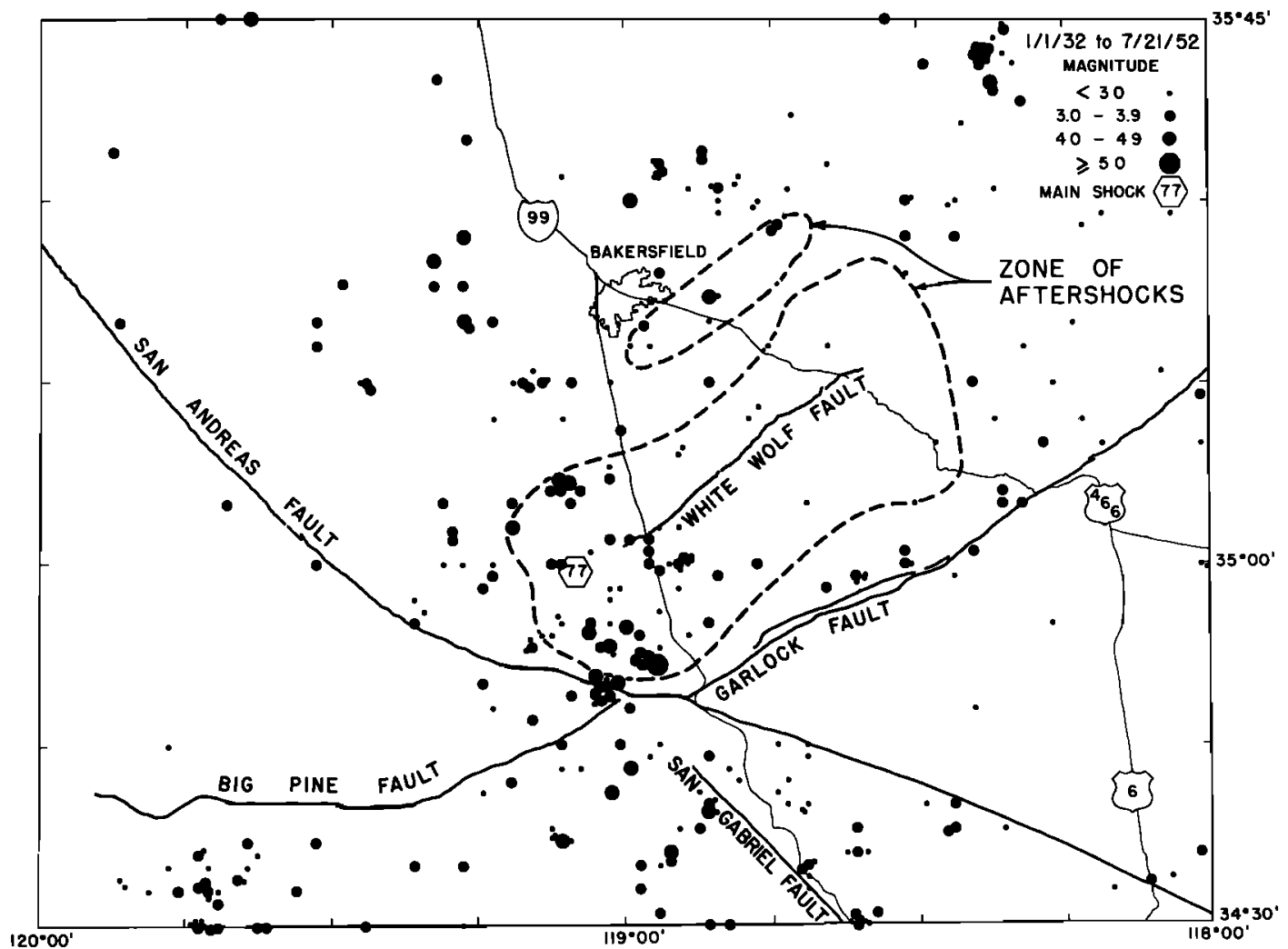

Fig. 2. Seismicity of the Bakersfield region from 1932 to the occurrence of the $M=7.7$ Kern County earthquake of July 21, 1952, as reported by Richter [1955a]. Clusters of solid circles represent groups of epicenters with the same reported location. The epicenter of the main shock, marked by a hexagon, and the aftershock zone, enclosed by the dashed lines, are from Richter [1955b].

tral California [Bolt et al., 1968; Bolt and Miller, 1971]. Northward from this area to Cape Mendocino the San Andreas fault displays a relatively low level of seismicity. The $35-\mathrm{km}$ segment of the San Andreas system south of Corralitos was one of the most active, generating 7 earthquakes with magnitudes greater than 4.0 between 1963 and 1967.

Three of these earthquakes $(M=4.4,4.2$, 5.4) occurred along the San Andreas fault zone in the vicinity of Watsonville during the late spring and summer of 1963 . Although no ground breakage was reported for these events and the instrumental locations indicate epicenters of about $5-10 \mathrm{~km}$ to the southwest of the fault zone, the earthquakes probably occurred much closer, perhaps along the fault itself, as more recent work on crustal velocities and station delay suggests [McEvilly, 1966; Wesson et al., 1973].
During the 3 years prior to the initiation of these moderate earthquakes this area displayed a relatively high level of seismicity. Udias [1965, 1969] reported an average of 2-3 earthquakes per month in the magnitude range 2.5-3.5 in the vicinity of Watsonville. The seismicity in this area for the 16 months preceding the first moderate earthquake ( $M=4.4$, May $7,1963)$ was much greater than the seismicity either to the northwest or in the adjoining segment of the San Andreas fault zone to the southeast, directly east of Salinas (Figure $3 a$ ). This relationship of a relatively active zone adjoined on either end by a quiet zone persisted throughout the sequence, although the active zone expanded northward. The large relative and absolute errors in the epicentral locations, suggested by the subsequent work on small earthquakes in the area by Lee et al. $[1972 a, b$, $c]$, make it difficult to draw firm conclusions 

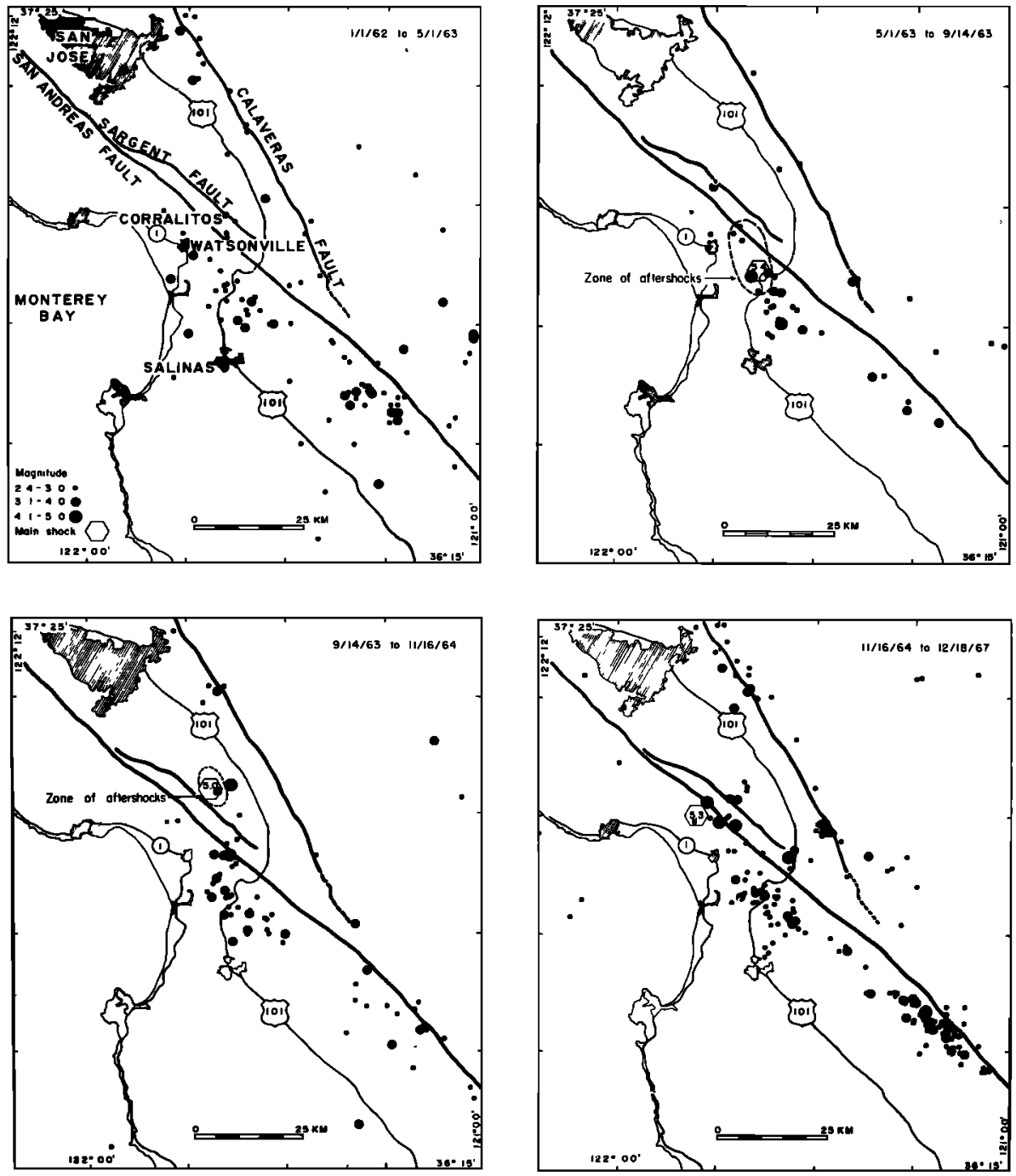

Fig. 3. Seismicity of the Watsonville-Corralitos area for the periods indicated as reported by UCB. The aftershock zone of the $M=5.4$ earthquakes of September 14, 1963, is after Udías [1965]. The aftershock zone of the $M=5.0$ Corralitos earthquake of November 16, 1964, is after $M c E$ villy [1966]. No aftershocks were reported for the $M=5.3$ Corralitos earthquake of September 7, 1967.

about the relation between the seismicity preceding the moderate earthquakes and the moderate earthquakes themselves. However, it is clear (1) that the $M=4.4$ earthquake of May 7 occurred at the northern end of the active zone, (2) that the $M=4.2$ earthquake of August 31 occurred toward the southern end of the active zone, (3) that the $M=5.4$ earthquake of September 14 occurred adjacent to the epicenter of the May 7 earthquake, and (4) that the aftershocks of the $M=5.4$ earthquake extended the zone of activity northwestward (Figure $3 b$ ).

After the $M=5.4$ earthquake on September 14,1963 , and its aftershocks, activity increased in the vicinity of the Sargent fault, culminating in an earthquake of $M=5.0$ on November 16, 1964 (McEvilly [1966]; see Figure 3c). In the 18 months prior to this earthquake, 3 earthquakes with magnitudes greater than or equal 
to 3.0 occurred within $5 \mathrm{~km}$ of the eventual epicenter (Figure $3 b, c$ ). After the $M=5.0$ earthquake, activity began to increase along the San Andreas fault immediately to the west of the epicenter (Figure $3 d$ ), including earthquakes of magnitudes 4.2 and 4.7 (October 14, 1966, and September 7, 1967). This activity contrasted markedly with the quiescence of the area in the preceding three years (Figure $3 a-c$ ). On December 18, 1967, a $M=5.3$ earthquake occurred in this area (Figure $3 d$ ). Relocation of the epicenters of the September 7, 1967, earthquake and the main shock by using the station corrections of Lee et al. [1972a] indicates that the epicenters of these two events were less than $2 \mathrm{~km}$ apart and that they both occurred at depths between 10 and $12 \mathrm{~km}$. No surface breakage or aftershocks were observed after the December 18 earthquake, and therefore no convenient estimate of the rupture surface is available, but a source dimension of a few kilometers can be inferred from the moment calculated for the earthquake by Wyss and Brune [1971] and from the magnitude by using scaling arguments [Dieterich, 1973].

1966 Parkfield-Cholame earthquakes. The Parkfield-Cholame earthquakes of June 28, 1966 $(M=5.1,5.5)$, occurred in an area that has been the site of several earthquakes in the magnitude 5-6 range in this century [McEvilly et $a l ., 1967]$. Their occurrence was therefore not surprising on a time scale of tens of years. McEvilly et al. [1967], Allen and Smith [1966], and Eaton [1967] have discussed earthquake activity in the months prior to June 28. The area is on the periphery of the UCB reporting area, and therefore the routine detection and location of small shocks is not as complete or accurate as might be desired. The estimated uncertainty in the locations for the 1966 preearthquake activity (Figure 4 ) is $2-5 \mathrm{~km}$ north of Parkfield to 5-10 km near Cholame.

Although only 11 earthquakes were located in 1966 preceding the earthquake, 43 events with $S-P$ intervals less than 4 sec (epicentral distances less than about $30 \mathrm{~km}$ ) were detected by the seismograph station at Gold Hill during the same period of time [Eaton, 1967]. Therefore, although it has been reported that no earthquakes were recorded in a 24-hour period during June [Allen and Smith, 1966], it is not true that the Parkfield-Cholame area was quiescent in the months preceding the earthquake. McEvilly et al. [1967] conclude that the 'first half of the year 1966 was characterized by apparently normal or slightly increased level of seismicity in the general Parkfield area.'

The 1966 preearthquake activity clusters just to the north of the epicenter of the main shock. Although the 1966 preearthquake activity shown in Figure 4 is not a complete set over the entire map area, T. V. McEvilly (personal communication, 1973) believes that it represents a complete picture to magnitude 2.5 along the San Andreas fault between Priest and Cholame and therefore that the apparent clustering to the north of the epicenter of the main shock is significant. In other words, the activity just north of the epicenter was significantly greater than that either in the aftershock zone to the south or along the fault farther north in the 6 months prior to the main shocks.

1968 Borrego Mountain earthquake. The San Jacinto-Imperial fault zone, which splays off from the San Andreas fault north of San Bernadino and extends southward to the Mexican border and beyond, has been one of the most active areas in California during this century [Allen et al., 1965]. Nine earthquakes of $M=6.0$ or greater have occurred along this $300-\mathrm{km}$-long zone of subparallel faults since 1915, including the $M=7.1$ EI Centro earthquake of 1940 . Ground breakage of the $M=$ 6.4 Borrego Mountain earthquake of April 9, 1968 , occurred along a $33-\mathrm{km}$ segment of the Coyote Creek fault, which lies within the San Jacinto Fault zone [Allen et al., 1968]. Aftershocks of the earthquake located by Hamilton [1972] define a zone of activity stretching about $50 \mathrm{~km}$ along the fault zone and two clusters, one $20 \mathrm{~km}$ northeast of the epicenter and one $20 \mathrm{~km}$ southwest of the epicenter. The breadth of the primary aftershock zone (in contrast to that of the Parkfield earthquake [Eaton et al., $1970 b]$ ), the observed slip on the Superstition Hills fault and on the San Andreas fault at the time of the earthquake [Allen et al., 1968], and the apparent aftershock activity in spatially separated regions all suggest a more complex nature for strain release in this area than for the Parkfield area.

The epicenter of the 1968 Borrego Mountain earthquake lies $30 \mathrm{~km}$ northeast of the $M=$ 


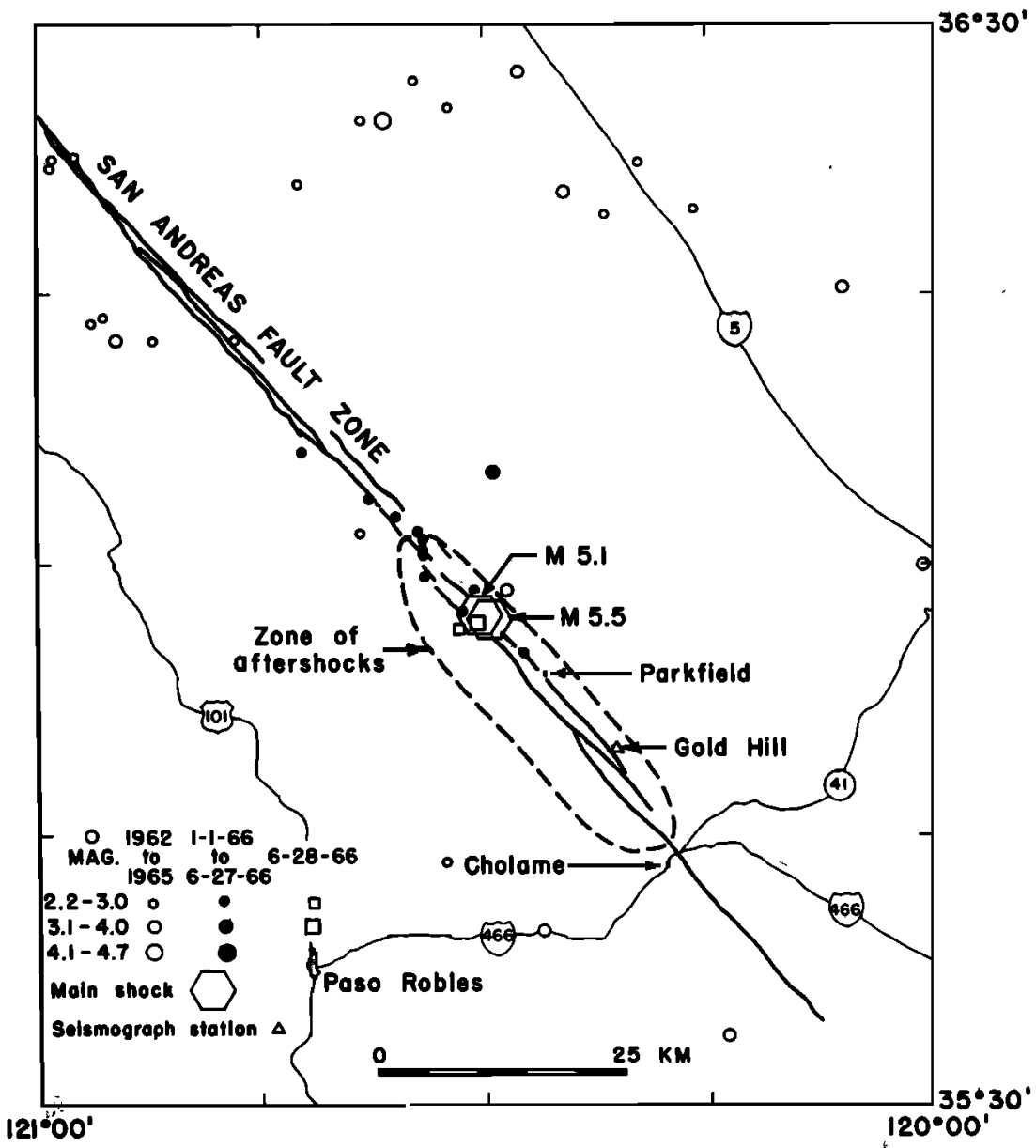

Fig. 4. Seismicity of the Parkfield-Cholame region recorded before the $M=5.1$ and $M=5.5$ earthquakes of June 28, 1966. Open circles represent epicenters from the UCB catalbg for 1962 through 1965. Locations reported by McEvilly et al. [1967] for 1966 appear as solid circles. Two shocks recorded on June 28, 1966, before the main shocks are shown as squares, and the epicenters of the moderate earthquakes appear as hexagons.

6.5 shock of October 21,1942 , and $10 \mathrm{~km}$ southeast of the $M=6.2$ earthquake of March 1954. Although the slip surfaces of these two earthquakes are not known in detail, Allen et al. [1968] state that 'no known major historic activity had occurred along the exact segment broken on April 9th.' Examination of records from a Caltech temporary station operated at Obsidian Butte, $47 \mathrm{~km}$ from the epicenter, by Allen and Nordquist [1972] led them to conclude that no detectable activity occurred in the days preceding the event. They also reported that the level of activity at the Obsidian Butte station during the four months preceding the earthquake was at a very low level.
Comparison of seismic activity in the Borrego Mountain region for the 5 years preceding April 1968 (Figure 5) with other active areas in California clearly demonstrates the extremely high level of activity over most of the San Jacinto fault zone. Aftershocks of the $M=4.7$ earthquake of May 21, 1967, and adjoining epicenters from the period 1963-1965 define an active zone $30 \mathrm{~km}$ to the northwest of the 1968 aftershock zone along the San Jacinto fault zone. A second zone of high activity lies to the south of the Salton Sea along an extension of the ground breakage of the $1940 \mathrm{El}$ Centro earthquake. Most of these events occurred in a 


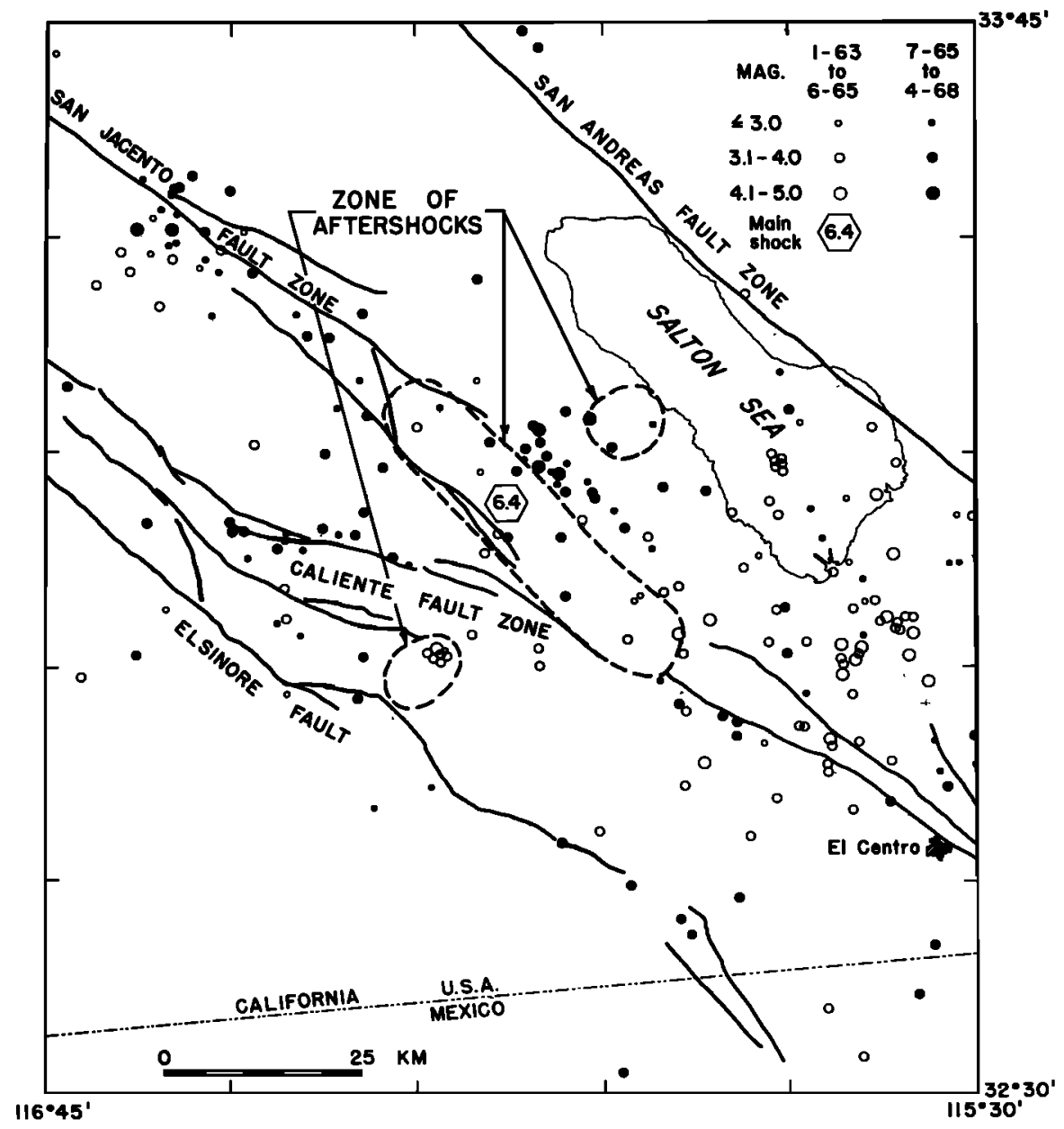

Fig. 5. Seismicity of the Borrego Mountain region from the Caltech catalog prior to the $M=6.4$ Borrego Mountain earthquake of April 9, 1968. The epicenter of the main shock and the aftershock zone are after Allen and Nordquist [1972].

swarm in June 1965 that included 5 events greater than magnitude 4.

The cluster of earthquakes adjoining the 1968 aftershock zone to the east occurred in late August 1965. The Caliente fault zone to the west of the aftershock zone showed an intensification of activity late in 1966 that continued through 1967.

The immediate epicentral region of the Borrego Mountain earthquake is not characterized by a high level of activity during the years preceding the earthquake, although it adjoins the clusters of activity recorded in August 1965. However, given the complexity of the geologic structure in this area and the complex interconnection of faults, the activity along the subparallel San Jacinto fault may be a result of the same phenomena observed to precede other earthquakes in this study.

1969 Santa Rosa earthquakes. Two earthquakes of $M=5.6,5.7$ shook the city of Santa Rosa on October 2, 1969. McEvilly [1970] characterized the area around Santa Rosa as having had 'a fairly active seismic history.' First motions and the distribution of aftershocks determined by Unger and Eaton [1970] show right lateral slip on a northwest-trending fault that runs subparallel to the Healdsburg fault to the north. Locations for the earthquakes reported by UCB for the 8 years preced- 
ing October 2, 1969 (Figure 6), are scattered, particularly for the smaller events, but clearly a relatively high level of activity existed in the immediate epicentral area. Of particular interest is the $M=4.6$ earthquake that occurred on April 25, 1968, with an epicenter nearly identical to that of the main shocks. No earthquake greater than magnitude 4 occurred in the vicinity of Santa Rosa for at least the previous 25 years [McEvilly, 1970]. The activity in the vicinity of Santa Rosa is isolated and represents a level of seismicity substantially greater than that associated with the San Andreas fault to the west, along which ground breakage occurred with the 1906 earthquake, or with the Healdsburg-Rodgers Creek fault zone either to the northwest or southeast of Santa Rosa.
1971 San Fernando earthquake. The San Fernando earthquake ( $M=6.4$ ) of February 9,1971 , occurred on faults not previously recognized as active, although ample geologic evidence existed before the earthquake to demonstrate movement along their traces in late Quaternary time [Wentworth and Yerkes, 1971]. The earthquake was accompanied by thrusting and left lateral slip along a westwardtrending, northward-dipping zone of thrust faults now termed the San Fernando fault zone. Prior to February 1971, no moderate or large earthquake had occurred in this area since instrumental epicenters have been determined. Allen [1971] discussed a large damaging earthquake that occurred somewhere in the area in 1893. In trenching fault scarps from the earthquake, Bonilla [1973] found wood frag-

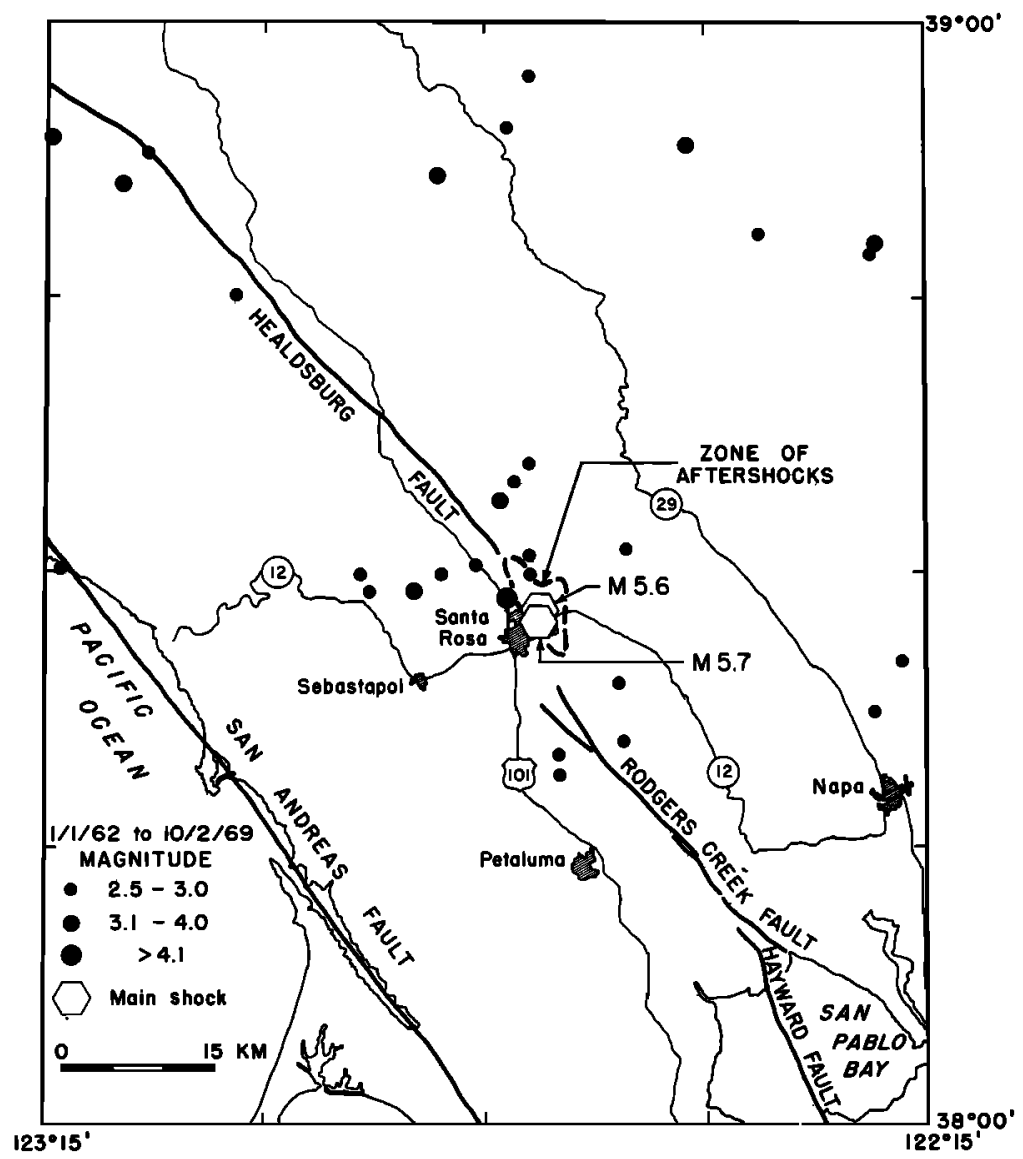

Fig. 6. Seismicity of the Santa Rosa area prior to the $M=5.6$ and $M=5.7$ Santa Rosa earthquakes of October 2, 1969, from the UCB catalog and McEvilly [1970]. The aftershock zone is after Unger and Eaton [1970]. 


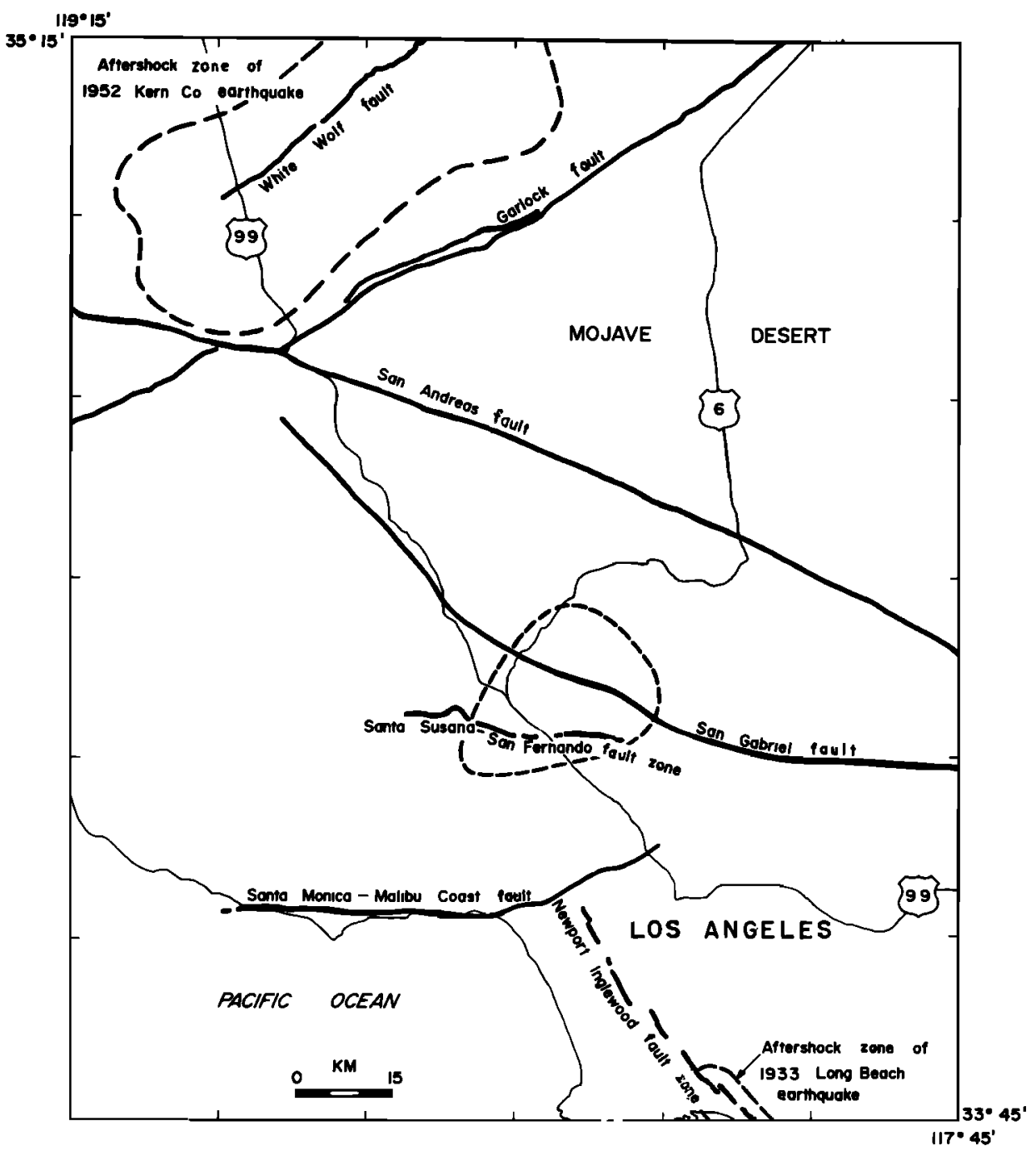

Fig. $7 a$.

Fig. 7. (a) Major faults, cultural features, and aftershock zones, and (b) seismicity preceding the $M=6.4$ San Fernando earthquake of February 9, 1971, from the Caltech catalog. The aftershock zone is after Allen et al. [1971] and Wesson et al. [1972]. The location of the main shock is after Allen et al. [1971].

ments in what he interpreted as collapse rubble from a scarp resulting from a previous earthquake. Dating by the carbon 14 method indicated an age of about 200 years, suggesting that an earthquake causing surface rupture occurred sometime in the 1700 's, perhaps the earthquake of 1769 [Richter, 1958]. Between 1963 and 1970, as reported by Caltech, three broad areas of activity in the San Fernando area are apparent (Figure $7 b$ ). Earthquakes in the northernmost area represent continuing activity in the aftershock zone of the 1952 Kern County earthquake. Earthquakes in the southernmost area occur over a wide area south of the Santa Monica mountains. The San Fernando earthquake and its aftershock zone are contained within the area of activity in the center of Figures $7 a, b$.

1972 Bear Valley earthquake. The Bear Valley earthquake of February 24, 1972 ( $M=$ 


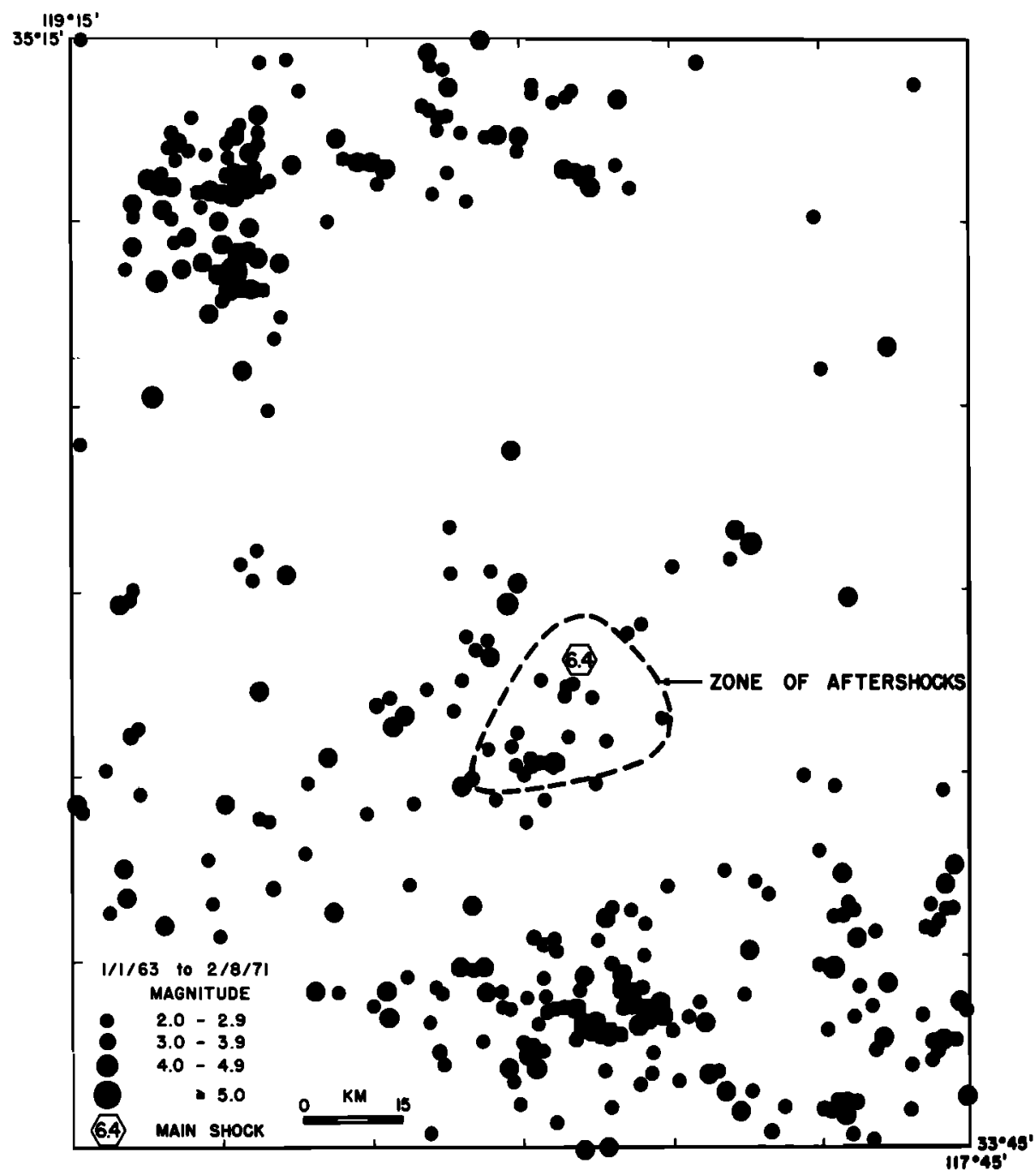

Fig. $7 b$.

5.0), occurred within a dense network of seismograph stations, affording the opportunity for an exceedingly detailed look at the distribution of small earthquakes preceding and following the main shock [Ellsworth and Wesson, 1972]. The epicenter of the main shock and those of its aftershocks were contained within one of the most active segments of this part of the San Andreas fault zone for the preceding 3 years (Figure 8). Earthquakes in the 17 months preceding the $M=5.0$ shock are shown in a vertical section parallel to the San Andreas fault in Figure 9, along with the locations of the aftershocks occurring in the first 3 days after the main event. The hypocenter of the main shock, or the point at which rupture began, occurred at a point on the fault surface that had been the site of several preceding events, including two in excess of $M=3.0$ in November 1970.

The cluster of events $11 \mathrm{~km}$ southeast of point $A$ at a depth of 5-6 km represents activity associated with a magnitude 4.0 earthquake December 29, 1971. A plot of the number of earthquakes with magnitudes greater than or equal to 1.0 per 2 - by $2-\mathrm{km}$ square on the fault 
Wesson and Ellsworth: Seismicity Preceding Earthquakgs

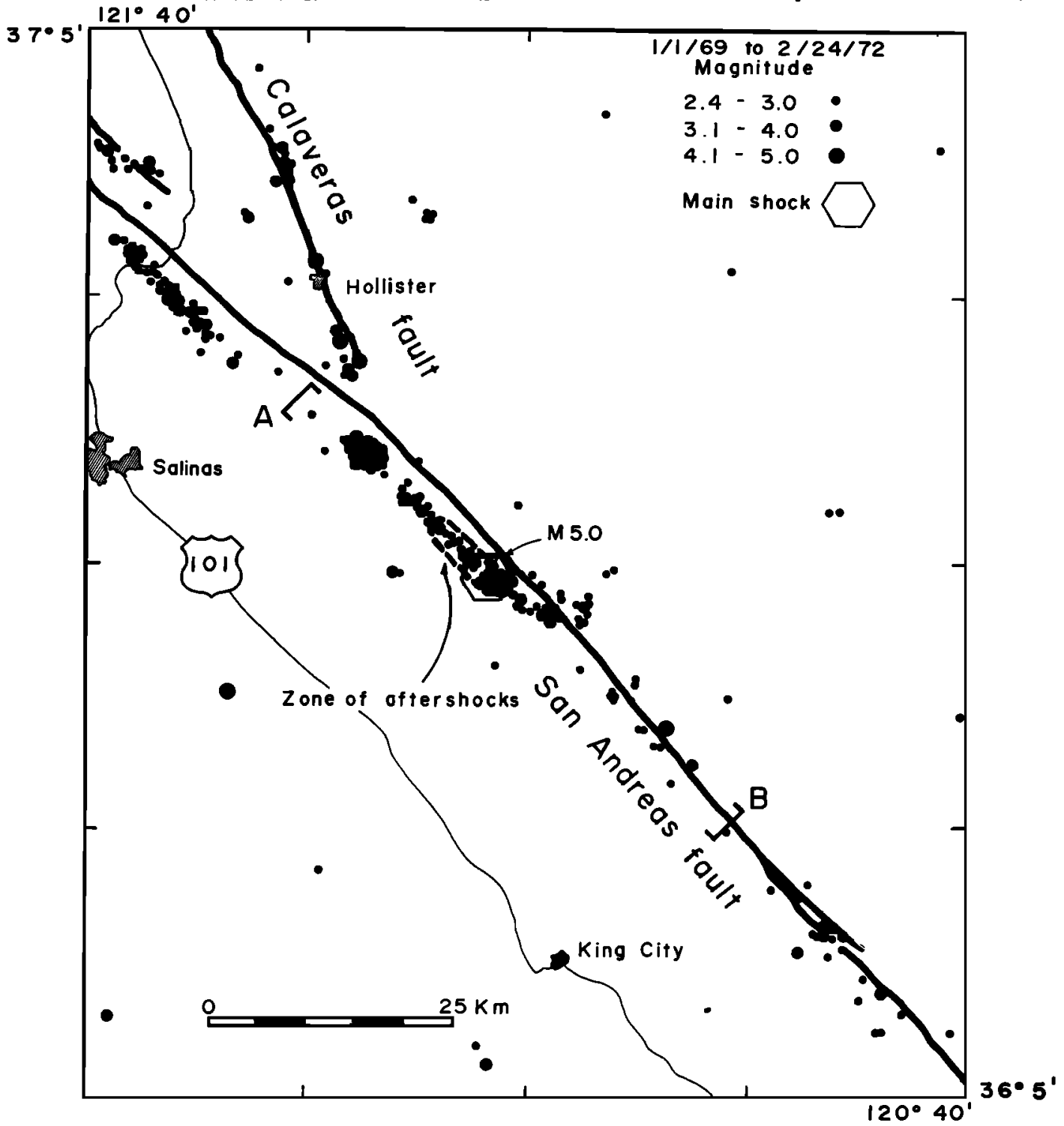

Fig. 8. Seismicity along the San Andreas fault system preceding the $M=5.0$. Bear Valley earthquake after Lee et al. [1972a, $b, c]$. The locations of the main shock and the aftershock zones are after Wesson et al. [1972].

surface [Figure 10] clearly indicates the occurrence of the hypocenter adjacent to a concentration of preceding earthquakes.

\section{A Conceptual Model}

In the seismic histories of the earthquakes examined in this study a clear tendency emerges for the hypocenter of a moderate earthquake to occur within a relatively active region. This is true on scales ranging from tens of kilometers, as in the Kern County earthquake, to the order of a kilometer, as in the 1972 Bear Valley earthquake. The case is strongest for this association in the situation where the data set is the most complete and the locations are the best (1972 Bear Valley earthquake).

These observations argue strongly that the stress distribution along typical fault zones in California is sufficiently inhomogeneous that, as the general level of tectonic stress is increased 

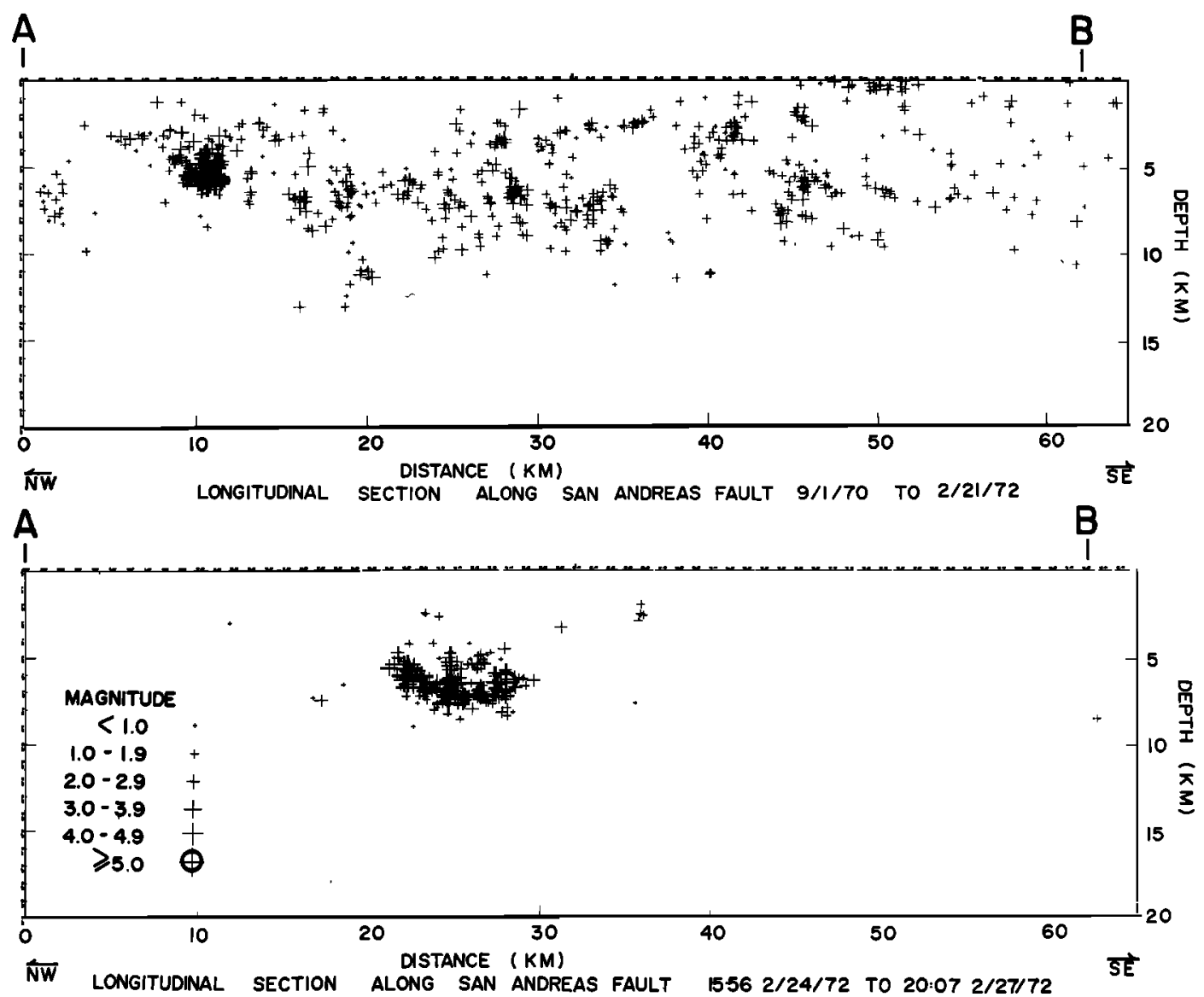

Fig. 9. Locations of earthquakes projected onto vertical section parallel to the San Andreas fault after Ellsworth and Wesson [1972]: (top) seismicity preceding $M=5.0$ Bear Valley earthquake and (bottom) first three days of aftershock activity.

(most probably as the result of plate motions), relatively small areas are brought up to failure before a large segment of a fault fails.

A conceptual model of how this process might occur, for example, along the San Andreas fault near Bear Valley, is depicted in Figure 11. No earthquakes are located at depths greater than about $15 \mathrm{~km}$, but the thickness of lithospheric plates is inferred to be much greater than 15 $\mathrm{km}$; therefore it is reasonable to assume that slip occurs without the generation of earthquakes below this depth. Fault creep is observed at the surface along some parts of the fault [cf. Savage and Burford, 1973; Nason, 1971], and it is also reasonable to assume that, at least locally, the zone of aseismic slip extends to the surface. (This is not necessary for the argument, because surface creep could also be generated by the stresses due to a pileup of screw dislocations beneath a horizontally infinite welded strip along the fault if the surface strength were low enough.) Along patches of the fault surface the physical properties or environmental factors (for example, coefficient of friction or pore pressure) are such that aseismic slip is at least retarded (high coefficient of friction or low pore pressure), perhaps as illustrated by the schematic displacement contours in Figure 11. Stresses will be set up on this patch as a result of the internal stresses of the dislocation loops surrounding it, and the strength may be decreased by secondary nonlinear effects such as flow of pore fluids. Our observations suggest that the difference be- 
A

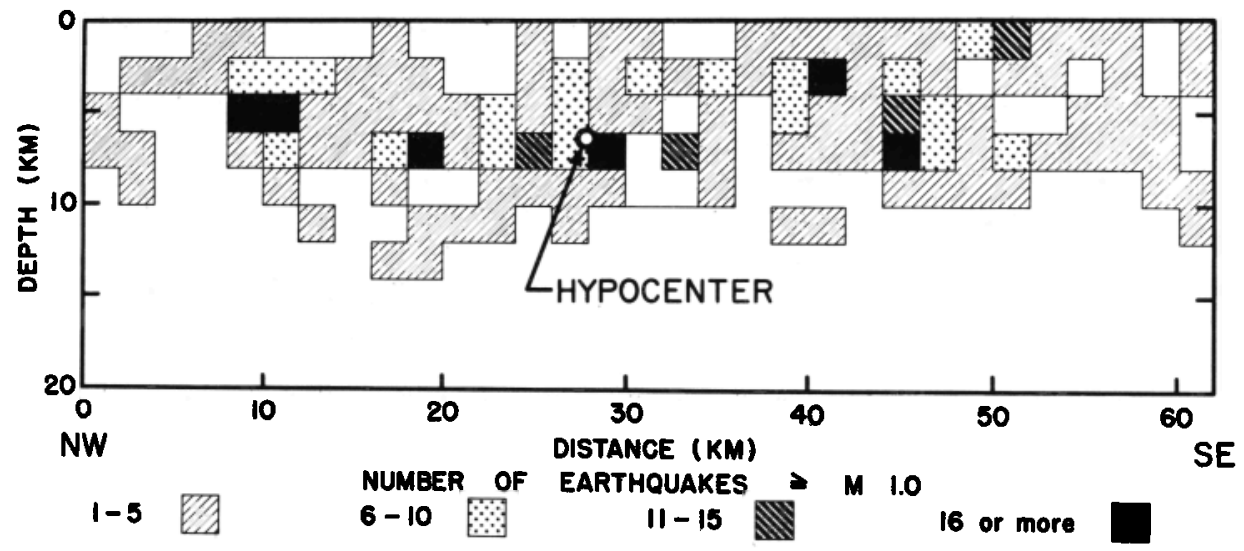

Fig. 10. Number of earthquakes $M \geq 1.0$ per 2- by $2-\mathrm{km}$ square plotted on vertical section parallel to San Andreas fault.

tween stress and strength are inhomogeneous on the patch, leading to small earthquakes where the failure criterion is met locally. Individual small earthquakes will lead to a spatial smoothing of the difference between stress and strength. This smoothing can be accomplished both by the 'priming model' of Weertman [1964, 1969], in which the internal stresses of the dislocations nucleated during slip are subtracted from the prestress, and by the flow of pore fluids and resulting changes in strength, as suggested by Nur and Booker [1972]. Consequently, when the shear stress on the patch is increased generally by continued or renewed aseismic slip, a larger area will reach failure at the same time because the spatial irregularities in the difference between stress and strength are smoothed out. This results in a larger earthquake. In this way the small earthquakes that precede moderate earthquakes are not only symptomatic of circumstances favorable to seismic slip; they may be a fundamental part of the process leading to failure in a moderate earthquake.

It is tempting to relate these observations to the results of small-scale experiments in the laboratory that demonstrate premonitory phenomena prior to fracture or sudden sliding in rock materials. Mogi [1962], Scholz [1968], and others have demonstrated that microfracturing occurs in unbroken rock prior to fracture and prior to frictional sliding on fracture surfaces. Generally, however, a rapid increase in the number of microfracturing events is observed just before failure. Our observations suggest that, if this analogy holds, the increase in activity must occur over years to tens of years. This sort of rapid increase in the number of small earthquakes preceding a moderate earthquake is not obvious before any of the earthquakes studied, although tenuous arguments might be made for such increase in the case of a few.

\section{Discussion}

Moderate earthquakes in California seem to occur in areas characterized by a relatively high level of small-earthquake activity. Prior to each of the earthquakes included in this study, the region containing the epicenter could not be considered quiescent over a period of years. Prior to most of the earthquakes, the area immediately surrounding the epicenter had a high level of activity relative to other segments of the same fault zone or other nearby fault zones. These moderate earthquakes occurred in a variety of seismic environments. The absolute level of small-earthquake activity varied immensely from locality to locality, and the moderate earthquakes included both thrust and strike-slip mechanisms. The preceding activity occurred predominantly on the same fault as the moderate earthquake, but the activity preceding the Borrego Mountain earthquake appeared to occur on a parallel fault 10 $\mathrm{km}$ east of the strand along which ground 


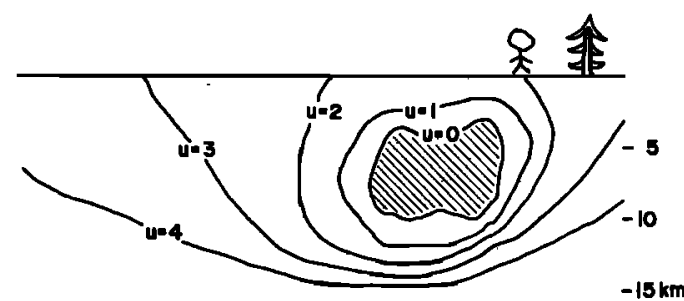

$-15 \mathrm{~km}$

Fig. 11. Conceptual model of the vertical distribution of relative displacement $u$ along a section of a fault that slips by creep at depth and around a patch that slips only during earthquakes, in arbitrary units.

breakage occurred. In some of the areas, moderate earthquakes are frequent events; in other areas they are infrequent. Moderate earthquakes have occurred near Parkfield several times in this century [McEvilly et al., 1967]. In contrast, the San Fernando area had not had a moderate earthquake in this century until 1971.

The occurrence of a small earthquake clearly requires two physical conditions. First, the stress in some region about the hypocenter must exceed the breaking or frictional strength of the fault. Second, the nature of the breaking or sliding surface, at least in the immediate vicinity of the hypocenter, must be conducive to the accumulation and sudden release of strain energy. These conditions are required for the occurrence of a moderate or large earthquake as well. Some evidence exists, however, that moderate and large earthquakes may be complex, multiple events [Wyss and Brune, 1967; Trifunac and Brune, 1970], so that these conditions may not be required over the entire slip surface, but only on parts of it.

Fedotov [1965], Mogi [1968b, 1969], Sykes [1971], Kelleher [1972], and Kelleher et al. [1973] have suggested that along primary plate boundaries such as the Kurile-Kamchatka, Aleutian-Alaska, and South American seismic zones, great earthquakes $(M>7.9)$ occur in 'gaps' between the aftershock zones of previous great earthquakes. The earthquakes that we studied included no great earthquakes, but an extrapolation of our observations suggests that a great earthquake would be preceded by a relatively high level of small and moderate earthquake activity. This has been suggested for the 1906 San Francisco earthquake by Tocher
[1959]. It seems quite important that seismicity studies aimed at determining the level of small earthquake activity be carried out in these gaps. The analysis by Tobin and Sykes [1966] of seismicity in Alaska for the 10-year period prior to the Alaska earthquake of March 28, 1964, suggests that considerable activity was clustered at each end of the aftershock zone. In particular, the activity in the northeastern end of the aftershock zone clustered near the epicenter of the main shock. Kelleher and Savino [1973] observed a concentration of activity in the vicinity of the epicenter preceding several large earthquakes but not preceding the 1972 Sitka, Alaska, earthquake ( $M=7.6$ ).

Considerable disagreement exists about the relation between seismicity, strain, fault creep, and geologic structure and the potential for a great earthquake in the apparent gap along the San Andreas fault in central California [Allen, 1968; Wallace, 1970; Scholz and Fitch, 1969, 1970, 1971; Savage and Burford, 1970, 1971]. This 175-km-long segment of the fault, terminated on the north by the fault breakage of the 1906 San Francisco earthquake and on the south by the fault breakage of the 1857 Fort Tejon earthquake, is substantially more active than either of the adjoining segments at the level of small and moderate earthquakes but has not been the site of an historic great earthquake. Analysis of the strain and creep data [Savage and Burford, 1970, 1971] suggests that strain is not accumulating at the present time within the resolution of the measurements.

The absence of strain aecumulation at the present time (last few tens of years) may be a relatively steady state phenomenon, as was suggested by Wallace [1970] and Allen [1968], or it may be that the strain does not accumulate linearly with time. For example, the rate of strain accumulation might decrease as the effective stress approaches the ultimate strength of the fault. The observation that a high level of small-earthquake activity exists along this segment does not distinguish between these two possibilities. It implies only that the difference between the effective stress and the frictional strength approaches zero. We cannot distinguish between a high level of shear stress or a low frictional strength. To resolve this question, we require either (1) measurements of stress and fluid pressure, (2) a better understanding of the 
strength, or (3) evidence from the geologic record on whether or not great earthquakes have occurred along this segment in Holocene time.

\section{Conclusion}

On the basis of these observations of the seismicity preceding moderate earthquakes we conclude that the occurrence of substantial small earthquake activity along a particular fault zone is diagnostic of (and in all probability a fundamental part of) the tectonic processes leading to a moderate earthquake in California. Although intuitive arguments can be made suggesting that a sustained period of quiescence is required to accumulate sufficient elastic strain to generate a moderate earthquake, our observations suggest, and elementary physical arguments support, the hypothesis that local stress concentrations lead to the occurrence of small earthquakes prior to moderate earthquakes. The regional observations (with the possible exception of the Borrego Mountain earthquake) are at least consistent with, and in most instances support, this hypothesis. The detailed observations of the small earthquakes preceding the 1972 Bear Valley earthquake are unequivocal.

The regional observations presented here have potential implications for the analysis of seismic risk. Moderate earthquakes in California seem to occur along segments of fault zones characterized by a relatively high level of activity. This seismicity is high relative to adjacent faults or segments of fault zones, which, on the basis of geologic criteria for recency of displacement, would be considered equally likely to be the locations of moderate earthquakes.

The problem arises, however, of a great earthquake, the hypocenter of which is along an active segment of a fault, but which ruptures into an adjacent quiescent segment, as suggested by Weertman [1971]. Until the circumstances leading to great earthquakes are better understood and capable of measurement, the usefulness of an analysis of seismic risk for moderate earthquakes is limited.

The detailed observations of the small earthquakes preceding the moderate earthquakes near Bear Valley and the suggested persistence through time of small areas of the fault plane being close to failure offer a potential tool for mapping this property along fault zones.
Many details of the relation between the small earthquakes that precede moderate earthquakes and the moderate earthquakes themselves remain unsolved. However, with the increased density of seismograph stations in California, it is hoped that these questions can be resolved and that the potential uses of this information for the prediction of moderate and larger earthquakes can be realized.

Acknowledgments. Wayne Thatcher, R. M. Hamilton, J. H. Healy, C. B. Raleigh, J. H. Kelleher, and T. V. McEvilly read the manuscript and offered numerous valuable suggestions. Discussions with J. C. Savage, R. O. Burford, R. A. Page, and J. P. Eaton were also stimulating. We thank J. A. Hileman of the Seismological Laboratory, California Institute of Technology, for help in obtaining a copy of the Caltech earthquake catalog on magnetic tape.

Research was carried out while one of the authors (R. L. Wesson) was pursuing an NRCUSGS Post-Doctoral Research Associateship. Parts of this work were done in cooperation with the Division of Reactor Development and Technology, U.S. Atomic Energy Commission.

Publication authorized by the Director, U.S. Geological Survey.

\section{ReFerences}

Allen, C. R., Tectonic environment of seismically active and inactive areas along the San Andreas fault system, Proceedings of Conference on Geologic Problems of the San Andreas Fault System, Stanford Univ. Publ. Geol. Sci., 11, $70-82,1968$.

Allen, C. R., Seismological environment, in the San Fernando, California, earthquake of February 9, 1971, U.S. Geol. Surv. Prof. Pap. 798, $7,10,1971$.

Allen, C. R., and J. M. Nordquist, Borrego Mountain earthquake: Foreshock, main shock, and larger aftershocks, U.S. Geol. Surv. Prof. Pap. 787, 16-23, 1972.

Allen, C. R., and S. W. Smith, Pre-earthquake and post-earthquake surficial displacements, Bull. Seismol. Soc. Amer., 56, 966, 1966.

Allen, C. R., P. St. Armand, C. F. Richter, and J. M. Nordquist, Relationship between seismicity and geologic structure in the southern California region, Bull. Seismol. Soc. Amer., 55, 753-797, 1965.

Allen, C. R., A. Grantz, J. N. Brune, M. M. Clark, R. V. Sharp, T. G. Theodore, E. W. Wolfe, and M. Wyss, The Borrego Mountain, California, earthquake of 9 April 1968: A preliminary report, Bull. Seismol. Soc. Amer., 58, 1183-1186, 1968.

Allen, C. R., G. R. Engen, T. C. Hanks, J. M. Nordquist, and W. R. Thatcher, Main shock and larger aftershocks of the San Fernando 
earthquake of February 9 through March 1, 1971, US. Geol. Surv. Prof. Pap. 783, 17-20, 1971.

Bolt, B. A., and R. D. Miller, Seismicity of northern and central California, 1965-1969, Bull. Seismol. Soc. Amer., 61, 1831-1847, 1971.

Bolt, B. A., C. Lomnitz, and T. V. McEvilly, Seismological evidence on the tectonics of central and northern California and the Mendocino escarpment, Bull. Seismol. Soc. Amer., 58, 1725-1768, 1968.

Bonilla, M. G., Trench exposures across surface fault ruptures associated with the San Fernando earthquake, in Geological and Geophysical Studies, vol. 3, San Fernando, California, Earthquake of February 9, 1971, edited by L. M. Murphy, National Oceanic and Atmospheric Administration, Washington, D.C., in press, 1973.

Brown, R. D., Jr., J. G. Vedder, R. E. Wallace, E. F. Roth, R. F. Yerkes, R. O. Castle, A. O. Waanonen, R. W. Page, and J. P. Eaton, The Parkfield-Cholame, California, earthquakes of June-August 1966-Surface geologic effects, water-resources aspects, and preliminary seismic data, U.S. Geol. Surv. Prof. Pap. 679, 66 pp. 1967.

Brune, J. N., and C. R. Allen, A micro-earthquake survey of the San Andreas fault system in southern California, Bull. Seismol. Soc. Amer., 57, 277-296, 1967.

Bulwalda, J. P., and P. St. Armand, Geological effects of the Arvin-Tehachapi earthquake, Earthquakes in Kern County, California, during 1952, Calif. Div. Mines Geol. Bull., 171, 41-56, 1955.

Byerly, P., Earthquakes off the coast of northern California, Bull. Seismol. Soc. Amer., 27, 7396, 1937.

Clark, M. M., A. Grantz, and M. Rubin, Holocene activity of the Coyote Creek fault as recorded in the sediments of Lake Cahuilla, U.S. Geol. Surv. Prof. Pap. 787, 112-130, 1972.

Dibblee, T. W., Jr., Geology of the southeastern margin of the San Joaquin Valley, California, Earthquakes in Kern County, California, during 1952, Calif. Div. Mines Geol. Bull., 171, 23-34, 1955.

Dieterich, J. H., A deterministic near-field source model, paper presented at Fifth World Conference on Earthquake Engineering, Int. Ass. for Earthquake Eng., Rome, June 25-29, 1973.

Eaton, J. P., Instrumental seismic studies, The Parkfield-Cholame, California, Earthquakes of June-August 1966-Surface Geologic Effects, Water-Resources Aspects, and Preliminary Seismic Datr, U. S. Geol. Surv. Prof. Pap. 579, $57-65,1967$.

Eaton, J. P., W. H. K. Lee, and I. C. Pakiser, Use of microearthquakes in the study of the mechanics of earthquake generation along the San Andreas fault in central California, Tectonophysics, 9, 259-282, $1970 a$.

Eaton, J. P., M. E. O’Neill, and J. N. Murdock,
Aftershocks of the 1966 Parkfield-Cholame, California, earthquake: A detailed study, Bull. Seismol. Soc. Amer., 60, 1151-1197, $1970 b$.

Ellsworth, W. L., and R. L. Wesson, Earthquakes near Bear Valley, California (abstract), Eos Trans. $A G U, 53,1042,1972$.

Fedotov, S. A., Regularities in the distribution of strong earthquakes in Kamchatka, the Kurile Islands, and northeastern Japan (in Russian), Tr. Inst. Fiz. Zemli Akad. Nauk SSSR, no. 36, 66, 1965.

Fedotov, S. A., On seismic cycle, possibility of quantitative seismic regionalization and longterm seismic prediction (in Russian), in Seismic Regionalization of the U.S.S.R. edited by S. V. Medvedev, pp. 121-150, Nauka, Moscow, 1968. Hamilton, R. M., Aftershocks of the Borrego Mountain earthquake from April 12 to June 12, 1968, U.S. Geol. Surv. Prof. Pap. 787, 31-54, 1972.

Kelleher, J. A., Rupture zones of large South American earthquakes and some predictions, $J$. Geophys. Res., 77, 2087-2103, 1972.

Kelleher, J. A., and J. M. Savino, Seismic preconditions of the 1972 Sitka earthquake and several other large earthquakes (abstract), Eos Trans. $A G U, 64,370,1973$.

Kelleher, J. A., L. R. Sykes, and J. Oliver, Possible criteria for predicting earthquake locations and their application to major plate boundaries of the Pacific and the Caribbean, $J$. Geophys. Res. 78, 2547-2585, 1973.

Keylis-Borok, V. I., and L. N. Malinovskaya, On regularity in the occurrence of strong earthquakes, J. Geophys. Res., 69, 3019-3024, 1964.

Lee, W. H. K., Earthquakes in the greater San Francisco Bay region: 1969-1971 (abstract), Eos Trans. $A G U, 62,815,1971$.

Lee, W. H. K., J. C. Roller, P. G. Bauer, and J. D. Johnson, Catalog of earthquakes along the San Andreas fault system in central California for the year 1969 , open file report, 48 pp., U.S. Geological Survey, Washington, D.C., $1972 a$.

Lee, W. H. K., J. C. Roller, K. L. Meagher, and R. E. Bennett, Catalog of earthquakes along the San Andreas fault system in central California for the year 1970, open file report, 73 pp., U.S. Geological Survey, Washington, D.C., $1972 b$.

Lee, W. H. K., K. L. Meagher, R. E. Bennett, and E. E. Matamoros, Catalog of earthquakes along the San Andreas fault system in central California for the year 1971, open file report, 67 pp., U.S. Geological Survey, Washington, D.C., $1972 c$.

McEvilly, T. V., The earthquake sequence of November 1964 near Corralitos, California, Bull. Seismol. Soc. Amer., 56, 755-773, 1966.

McEvilly, T. V., Magnitudes, epicenters, and fault plane solutions, in the Santa Rosa earthquakes of October, 1969, Miner. Inform. Serv., 23, 44-48, 1970 . 
McEvilly, T. V., W. H. Bakun, and K. B. Casady, The Parkfield, California, earthquake of 1966, Bull. Seismol. Soc. Amer., $57,1221-1244,1967$.

Mogi, K., Study of the elastic shocks caused by the fracture of heterogeneous materials and its relation to earthquake phenomena, Bull. Earthquake Res. Inst. Tokyo Univ., 40, 125, 1962.

Mogi, K., Development of aftershock areas of great earthquakes, Bull. Earthquake Res. Inst., Tokyo Univ., $46,175-203,1968$.

Mogi, K., Some features of recent seismic activity in and near Japan, 1, Bull. Earthquake Res. Inst., Tokyo Univ., 46, 1225-1236, 1968 .

Mogi, K., Some features of recent seismic activity in and near Japan, 2, Activity before and after great earthquakes, Bull. Earthquake Res. Inst., Tokyo Univ., 47, 395-417, 1969.

Nason, R. D., Measurements and theory of fault creep slippage in central California, Roy. Soc. N.Z. Bull., 9, 181-187, 1971.

Nur, A., and J. R. Booker, Aftershocks caused by pore fluid flow?, Science, 175, 885-887, 1972.

Oakeshott, G. B., The Kern County earthquakes in California's geologic history, Earthquakes in Kern County, California, during 1952, Calif. Div. Mines Geol. Bull., 171, 15-22, 1955.

Page, R. A., Crustal deformations on the Denali fault, Alaska, 1942-1970, J. Geophys. Res., 77, 1528-1533, 1972.

Richter, C. F., Seismic history in the San Joaquin Valley, California, Earthquakes in Kern County, California, during 1952, Calif. Div. Mines Geol. Bull., 171, 143-146, 1955a.

Richter, C. F., Foreshocks and aftershocks, Earthquakes in Kern County, California, during 1952, Calif. Div. Mines Geol. Bull., 171, 177-198, $1955 b$.

Richter, C. F., Elementary Seismology, 768 pp., W. H. Freeman, San Francisco, Calif., 1958.

Ryall, A., W. U. Savage, and D. B. Slemmons, Seismic potential in the western basin and range/eastern Sierra Nevada region, Nevada and California (abstract), Eos Trans. $A G U, 58$, 442, 1972.

Savage, J. C., and R. O. Burford, Strain accumulation in California, Bull. Seismol. Soc. Amer., 60, 1877-1896, 1970.

Savage, J. C., and R. O. Burford, Discussion of paper by C. H. Scholz and T. J. Fitch, 'Strain accumulation along the San Andreas fault,' $J$. Geophys. Res., 76, 6469-6479, 1971.

Savage, J. C., and R. O. Burford, Geodetic determination of relative plate motion in central California, J. Geophys. Res., 78, 832-845, 1973.

Scholz, C. H., Microfracturing and inelastic deformation of rock in compression, $J$. Geophys. Res., 73, 1417-1432, 1968.

Scholz, C. H., and T. J. Fitch, Strain accumulation along the San Andreas fault, J. Geophys. Res., 74, 6649-6666, 1969.

Scholz, C. H., and T. J. Fitch, Strain and creep in central California, J. Geophys. Res., 76, $4447-4453,1970$.

Scholz, C. H., and T. J. Fitch, Reply to comments by J. C. Savage and R. O. Burford, J. Geophys. Res., 76, 6480-6484, 1971.

Sykes, L. R., Aftershock zones of great earthquakes, seismicity gaps, and earthquake prediction for Alaska and the Aleutians, J. Geophys. Res., 76, 8021-8041, 1971.

Tobin, D. G., and L. R. Sykes, Relationship of hypocenters of earthquakes to the geology of Alaska, J. Geophys. Res., 71, 1659-1667, 1966. Tocher, D., Seismic history of the San Francisco Bay region, San Francisco Earthquakes of March 1957, Calif. Div. Mines Spec. Rep. 57, 39-48, 1959.

Trifunac, M. D., and J. N. Brune, Complexity of energy release during the Imperial Valley, California, earthquake of 1940, Bull. Seismol. Soc. Amer., 60, 137-160, 1970.

Udías, A., A study of the aftershocks and focal mechanism of the Salinas-Watsonville earthquakes of August 31 and September 14, 1963, Bull. Seismol. Soc. Amer., 55, 85-106, 1965.

Udías, A., Earthquake sequences and seismicity of the Watsonville region of central California, Ann. Geofis., 22, 115-145, 1969.

Unger, J. D., and J. P. Eaton, Aftershocks of the October 1, 1969, Santa Rosa, California, earthquakes (abstract), Geol. Soc. Amer. Abstr. Programs, 2, 155, 1970.

Wallace, R. E., Earthquake recurrence intervals on the San Andreas fault, Geol. Soc. Amer. Bull., 81, 2875-2890, 1970.

Weertman, J., Continuum distribution of dislocations on faults with finite friction, Bull. Seismol. Soc. Amer., 54, 1035-1058, 1964.

Weertman, J., Dislocation motion on an interface with friction that is dependent on sliding velocity, J. Geophys. Res., 74, 6617-6622, 1969.

Weertman, J., Allen-Wallace zone of the San Andreas fault and discontinuous yielding of a slip band in a crystal, Nature, 231, 9-10, 1971.

Wentworth, C. M., and R. F. Yerkes, Geologic setting and activity of faults in the San Fernando area, California, The San Fernando, California, earthquake of Feb. 9, 1971, US. Geol. Surv. Prof. Pap. 783, 6-16, 1971.

Wesson, R. L., and D. H. Wilson, Faulting in the San Fernando earthquake of February 9, 1971 (abstract), Eos Trans. AGU, 58, 444, 1972.

Wesson, R. L., R. E. Bennett, and K. L. Meagher, Catalog of earthquakes along the San Andreas fault system in central California, JanuaryMarch, 1972, open file report, 60 pp., U.S. Geological Survey, Washington, D.C., 1972.

Wesson, R. L., J. C. Roller, and W. H. K. Lee, Time-term analysis and geologic interpretation of seismic traveltime data from the Coast Ranges of central California, Bull. Seismol. Soc. Amer., 63, 1447-1471, 1973. 
Wyss, M., and J. N. Brune, The Alaska earthquake of 28 March 1964: A complex multiple rupture, Bull. Seismol. Soc. Amer., 67, 1017-1023, 1967.

Wyss, M., and J. N. Brune, Regional variations of source properties in southern California esti- mated from the ratio of short- to long-period amplitudes, Bull. Seismol. Soc. Amer., 61, 11531168, 1971.

(Received May 24, 1973; revised August 10, 1973.) 